\title{
PENGARUH KECERDASAN EMOSIONAL DAN KECERDASAN SPIRITUAL TERHADAP KINERJA AUDITOR KANTOR BADAN PEMERIKSA KEUANGAN WILAYAH LAMPUNG
}

(Study Kasus di Kantor BPK Wilayah Lampung)

\author{
Rosmiaty Tarmizi, Universitas Bandar Lampung \\ Gilang Suryo Dewantoro, Universitas Bandar Lampung \\ Suwandi, Universitas Bandar Lampung
}

\begin{abstract}
The purpose of this research is to analyze influence emotional intelligence and wit spiritual on the performance bpk auditor office region lampung. While hypothesis advanced by is there are good influence simultaneously or by partial between intelligence emotional and intelligence spiritual on the performance auditor. The research found that simultaneously emotional intelligence and wit spiritual effect on performance auditor. Results in partial show that emotional intelligence and wit spiritual effect on performance auditor. Then can be concluded that emotional intelligence and wit spiritual effect on auditor good performance simultaneously or by partial.
\end{abstract}

Keywords : Emotional intelligence, spiritual intelligence, auditor office

\section{LATAR BELAKANG}

Memasuki abad 21, legenda atau paradigma lama tentang anggapan bahwa $I Q$ (Intelligence Quotient) sebagai satu-satunya tolak ukur kecerdasan, yang juga sering dijadikan parameter keberhasilan dan kesuksesan kinerja sumber daya manusia, digugurkan oleh munculnya konsep atau paradigma kecerdasan lain yang ikut menentukan terhadap kesuksesan dan keberhasilan seseorang dalam hidupnya. Menurut penelitian yang dilakukan Goleman ((2006:31) mnyebutkan pengaruh IQ hanyalah 20\% saja, sedangkan 80\% dipengaruhi oleh faktor lain termasuk di dalamnya adalah kecerdasan emosional (EQ) dan kecerdasan spiritual (SQ). sehingga dengan kata lain IQ dapat dikatakan gagal dalam menerangkan atau berpengaruh terhadap kesuksesan seseorang.

Dalam rangka mewujudkan good governance, dan akuntabilitas pengendalian dengan melakukan pemeriksaan dari pihak internal maupun eksternal organisasi sangat penting untuk dilaksanakan. Dalam lingkungan pemerintah daerah Badan Pemeriksa Keuangan (BPK) berfungsi sebagai auditor eksternal. Untuk menjalankan fungsi audit tersebut, maka Badan Pemeriksa Keuangan didukung oleh kinerja auditornya. Auditor memiliki peran penting dalam menjalankan fungsi pengendalian dan pemeriksaan terhadap kegiatan pemerintah daerah termasuk di dalamnya menilai efektifitas standar pengendalian intern dan menilai apakah kegiatan operasional telah dilaksanakan sesuai dengan standar akuntansi pemerintahan yang berlaku. Oleh karenanya,dalam melaksanakan pemeriksaan seorang auditor harus mampu menggabungkan pengetahuan, pengalaman serta independensinya dalam menghasilkan audit yang berkualitas. Fungsi audit akan efektif dan optimal apabila 
ditunjang oleh kinerja auditornya. Dan untuk meningkatkan kinerjanya, seorang auditor tidak hanya membutuhkan kecerdasan intelektual saja, tetapi dibutuhkan juga kecerdasan emosional dan spiritual. Kecerdasan emosional, diperlukan karena kecerdasan ini merupakan kemampuan bagi seorang auditor untuk memahami perasaan atau keinginan orang lain (pihak lain) dan keinginan atau perasaannya sendiri. Dengan memahami perasaan orang lain (pihak lain), seorang auditor akan mampu untuk mengetahui apa sebenarnya yang menjadi tujuan dan kehendak yang ingin dicapai oleh pihak yang menggunakan jasanya. Demikian juga yang berlaku bagi auditor pada kantor Badan Pemeriksa Keuangan, mereka harus mengetahui tujuan yang ingin dicapai oleh unit kerjanya sehingga auditor tersebut dapat menjalankan fungsinya dengan baik. Selain itu, dengan memahami perasaan atau keinginan dirinya sendiri, seorang auditor akan mempunyai kesadaran diri untuk mengembangkan serta memanfaatkan kemampuan yang dimiliki dengan sebaik mungkin, dengan didukung oleh pengaturan diri dan motivasi dalam bertindak dan mengambil keputusan untuk pekerjaannya, serta selalu terpacu untuk memberikan yang terbaik dalam pekerjaan yang dilakukan, sehingga dapat meningkatkan kinerja bagi auditor tersebut.

\section{TELAAH LITERATUR DAN PENGEMBANGAN HIPOTENSI}

\subsection{Tinjauan Pustaka}

Penelitian mengenai kecerdasan emosional sebelumnya telah dilakukan oleh Sayogya (2004). Penelitian tersebut mengkaji pengaruh kecerdasan emosional terhadap prestasi kerja auditor. Hasil penelitian itu menemukan pengaruh kecerdasan emosional terhadap prestasi kerja auditor. Steven J.Stein dan Howard dalam buku "Ledakan IQ" menyebutkan bahwa kecerdasan emosi dapat meningkatkan kinerja penjualan perusahaan-perusahaan terkemuka di dunia. Selain kecerdasan emosional juga terdapat kecerdasan spiritual, dimana istilah tersebut digagaskan oleh Danah Zohar. Danah Zohar menyatakan bahwa kecerdasan spiritual adalah kecerdasan yang mengangkat fungsi jiwa sebagai perangkat internal diri yang memiliki kemampuan dan kepekaan dalam melihat makna yang ada di balik kenyataan. Penelitian mengenai kecerdasan spiritual pernah dilakukan oleh Chakraborty (2004), yang melakukan penelitian tentang kecerdasan spiritual dan leadership. Spiritualitas berpengaruh terhadap bagaimana seseorang bersikap sebagai pemimpin.

\subsection{Kerangka Teoritis}

\subsubsection{Kecerdasan Emosional}

Kecerdasan (intellegence) berasal dari bahasa latin "intelligere" yang berarti menghubungkan atau menyatukan satu sama lain. Kecerdasan adalah daya reaksi penyesuaian yang cepat dan tepat, baik secara fisik atau mental terhadap pengalamanpengalaman baru, membuat pengalaman dan pengetahuan yang telah dimiliki siap untuk dipakai apabila dihadapkan pada fakta-fakta atau kondisi baru. Menurut W.Stern, kecerdasan adalah kesanggupan jiwa untuk dapat menyesuaikan diri dengan cepat dan tepat. Sedangkan menurut Alfred Binet, seorang tokoh utama perintis pengukuran intelligence yang hidup antara tahun 1857-1911, mendefinisikan inteligensi sebagai tindakan yang terdiri atas tiga komponen, yaitu:

a. Kemampuan untuk mengarahkan fikiran.

b. Kemampuan mengubah arah tindakan bila tindakan tersebut telah dilaksanakan.

c. Kemampuan mengkritik diri sendiri. 
Intelligence (kecerdasan) adalah kemampuan yang memiliki lima karakteristik umum yaitu kemampuan untuk belajar, mengambil manfaat dari pengalaman, berfikir secara abstrak, beradaptasi, dan memotivasi diri sendiri dalam menyelesaikan masalah secara tepat. Kata emosi berasal dari bahasa latin, yaitu emovere, yang berarti bergerak menjauh. Arti kata ini menyiratkan bahwa kecerdasan bertindak merupakan hal mutlak dalam emosi. Emosi merujuk pada suatu perasaan dan pikiran yang khas, suatu keadaan biologis dan psikologis, dan serangkaian kecenderungan untuk bertindak. Emosi pada dasarnya adalah dorongan untuk bertindak. Biasanya emosi merupakan reaksi terhadap rangsangan dari luar dan dalam diri individu. Dan beberapa emosi, yaitu:
a. Amarah
b. Kesedihan
c. Rasa takut
d. Kenikmatan
e. Cinta
f. Terkejut
g. Jengkel

Istilah kecerdasan emosi pertama kali dilontarkan oleh psikolog Petersolovey dari Harvard University dan John Mayer dari University of New Hampshire pada tahun 1990, dengan menyebutkan kualifikasi-kualifikasi emosi manusia yang meliputi empati, mengungkapkan dan memahami perasaan, pengendalian amarah, kemandirian, kemampuan menyesuaikan diri, kemampuan memecahkan masalah antar pribadi, ketekunan dan kesetiakawanan, keramahan, dan sikap hormat.

Kecerdasan Emosional (EQ) adalah suatu kecerdasan yang merujuk pada kemampuan mengenali perasaan diri sendiri dan perasaan orang lain, kemampuan memotivasi diri sendiri, dan kemampuan mengenali emosi dengan baik pada diri sendiri dan dalam berhubungan dengan orang lain . Kecerdasan emosional ke dalam lima unsur. Kelima unsur tersebut dikelompokan ke dalam dua kecakapan, yaitu kecakapan pribadi yang meliputi kesadaran diri, pengaturan diri dan motivasi, kecakapan sosial yang meliputi empati dan keterampilan sosial.

1. Kesadaran diri

Kesadaran diri merupakan dasar dari kecerdasan emosional yaitu merupakan kemampuan untuk memantau perasaan dari waktu ke waktu. Selain itu kesadaran diri juga berarti menetapkan tolak ukur yang realistis atas kemampuan diri dan kepercayaan diri yang kuat. Menyatakan bahwa saat kita semakin mengenal diri kita, kita akan lebih memahami apa yang kita rasakan dan lakukan. Pemahaman itu akan memberi kita kesempatan atau kebebasan untuk mengubah hal-hal yang ingin kita ubah mengenai diri kita dan menciptakan kehidupan yang kita inginkan. Kesadaran diri memang belum menjamin penguasaan emosi, namun merupakan salah satu prasyarat penting untuk mengendalikan emosi sehingga individu mudah menguasai emosi.

\section{Pengaturan diri di definisikan}

pengaturan diri dengan menangani emosi kita sedemikian sehingga berdampak positif kepada pelaksanaan tugas, peka terhadap kata hati dan sanggup menunda kenikmatan sebelum tercapainya sesuatu sasaran dan mampu pulih kembali dari tekanan emosi. Menangani perasaan agar perasaan dapat terungkap dengan tepat adalah kecakapan yang bergantung pada kesadaran diri. Menjaga agar emosi yang merisaukan tetap terkendali merupakan kunci menuju kesejahteraan emosi. 
Aristoteles dalam Nicomachean Ethnic menulis siapapun bisa marah, marah itu mudah. Tetapi, marah pada orang yang tepat, dengan kadar yang sesuai, pada waktu yang tepat, demi tujuan yang benar, dan dengan cara yang baik, bukanlah hal yang mudah. Davidson dalam Goleman menemukan bahwa orang yang tangguh sudah memulai menghambat rasa tertekan selama situasi stress berlangsung. Mereka adalah orang-orang yang optimistik dan berorientasi pada tindakan. Jika ada orang yang mengalami masalah dalam hidupnya, mereka langsung berfikir bagaimana cara memperbaikinya.

\section{Motivasi}

Motivasi berarti menggunakan hasrat kita yang paling dalam untuk menggerakkan dan menuntun seseorang menuju sasaran, membantu kita mengambil inisiatif dan bertindak sangat efektif dan untuk bertahan menghadapi kegagalan dan frustasi Motivasi yang paling ampuh adalah motivasi yang berasal dari dalam diri seseorang, Motivasi mendorong seseorang untuk berprestasi, dimana ia memiliki ketekunan untuk menahan diri dan mengendalikan dorongan hati, serta mempunyai perasaan motivasi yang positif yaitu: antusianisme, optimis, dan keyakinan diri.

\section{Empati}

Kemampuan berempati adalah kemampuan untuk mengetahui bagaimana perasaan orang lain, mampu memahami perspektif mereka, menumbuhkan hubungan saling percaya dan menyelaraskan diri dengan bermacam-macam orang. Kunci untuk memahami perasaan orang lain adalah mampu membaca pesan nonverbal seperti nada bicara, gerak-gerik, ekspresi wajah dan sebagainya.

\section{Keterampilan sosial}

Menurut Goleman keterampilan sosial berarti menangani emosi dengan baik ketika berhubungan dengan orang lain dan dengan cermat membaca situasi dan jaringan sosial, berinteraksi dengan lancar, menggunakan keterampilan-keterampilan ini untuk mempengaruhi dan memimpin, bermusyawarah dan menyelesaikan perselisihan dan untuk bekerja sama dan bekerja dalam tim. Salah satu kunci keterampilan sosial adalah seberapa baik atau buruk seseorang mengungkapan perasaan sendiri.

\section{Faktor-faktor yang mempengaruhi kecerdasan emosi:}

a. Faktor Internal

Faktor internal adalah apa yang ada dalam diri individu yang mempengaruhi kecerdasan emosinya. Faktor internal ini memiliki dua sumber yaitu segi jasmani dan segi psikologis. Segi jasmani adalah faktor fisik dan kesehatan individu, apabila fisik dan kesehatan seseorang dapat terganggu, dapat dimungkinkan mempengaruhi kecerdasan emosinya. Segi psikologis mencakup didalamnya pengalaman, perasaan, kemampuan berfikir dan motivasi.

\section{b. Faktor Eksternal}

Adalah stimulasi dan lingkungan di mana kecerdasan emosi berlangsung. Faktor eksternal meliputi:

1) Cara Stimulasi itu sendiri, kejenuhan stimulasi merupakan salah satu faktor yang mempengaruhi keberhasilan seseorang dalam memperlakukan kecerdasan emosi tanpa distorsi, dan

2) Lingkungan atau situasi khususnya yang melatarbelakangi proses kecerdasan emosi. 


\section{meningkatkan kecerdasan emosi:}

1) Membaca situasi

Dengan memperhatikan situasi sekitar, kita akan mengetahui apa yang harus dilakukan.

2) Mendengar dan menyimak lawan bicara

Dengarkan, simak pembicaraan dan maksud dari lawan bicara, agar tidak terjadi salah paham serta dapat menjaga hubungan baik.

3) Siap berkomunikasi

Jika terjadi suatu masalah, bicarakanlah agar tidak terjadi salah paham.

4) Tidak usah takut ditolak

Setiap usaha terdapat dua kemungkinan, diterima atau ditolak, jadi siapkan diri dan jangan takut ditolak.

5) Mencoba berempati

$E Q$ tinggi biasanya di dapat pada orang-orang yang mampu berempati atau bisa mengerti situasi yang dihadapi orang lain.

6) Pandai memilih prioritas

Ini perlu agar bisa memilih pekerjaan apa yang mendesak dan apa yang bisa ditunda.

7) Siap mental

Situasi apapun yang akan dihadapi kita harus menyiapkan mental sebelumnya.

8) Ungkapan lewat kata-kata

Katakan maksud dan keinginan dengan jelas dan baik, agar dapat saling mengerti.

9) Bersikap rasional

Kecerdasan emosi berhubungan dengan perasaan, namun tetap berfikir rasional.

10) Fokus

Konsentrasi diri pada suatu masalah yang perlu mendapat perhatian. Jangan memaksakan diri untuk menyelesaikan banyak masalah secara bersamaan.

\subsubsection{Kecerdasan Spiritual}

Kecerdasan spiritual adalah kecerdasan untuk menghadapi dan memecahkan persoalan makna dan nilai, yaitu menempatkan perilaku dan hidup manusia dalam konteks makna yang lebih luas dan kaya, serta menilai bahwa tindakan atau jalan hidup seseorang lebih bermakna dibandingkan dengan yang lain mendefinisikan kecerdasan spiritual sebagai kemampuan manusia yang berkenaan dengan usaha memberikan penghayatan bagaimana agar hidup ini lebih bermakna.

Kecerdasan spiritual membuat seseorang mengetahui atau menemukan arti penting dari segala sesuatu, ada beberapa indikasi dari kecerdasan spiritual yang telah berkembang dengan baik yang mencakup:

a. Kemampuan untuk bersikap fleksibel

b. Adanya tingkat kesadaran yang tinggi

c. Kemampuan untuk menghadapi dan memanfaatkan penderitaan

d. Kemampuan untuk menghadapi dan melampaui perasaan sakit

e. Kualitas hidup yang diilhami oleh visi dan nilai-nilai

f Keengganan untuk menyebabkan kerugian yang tidak perlu

g. Kecenderungan untuk berpandangan holistik

h. Kecenderungan untuk bertanya "mengapa" atau "bagaimana jika" dan berupaya untuk mencari jawaban-jawaban yang mendasar

i. miliki kemudahan untuk bekerja melawan konvensi

j. Spiritual non dogmatis 
Komponen ini merupakan nilai dari kecerdasan spiritual dimana didalamnya terdapat kemampuan untuk bersikap fleksibel, memiliki tingkat kesadaran yang tinggi, serta kemampuan untuk menghadapi dan memanfaatkan penderitaan, kualitas hidup yang diilhami oleh visi dan nilai.

\section{Faktor-faktor yang mempengaruhi kecedasan spiritual:}

Adapun faktor utama yang mempengaruhi kecerdasan spiritual yaitu

a. Faktor genetik atau bawaan

b. Faktor lingkungan.

\subsubsection{Kinerja}

Kinerja adalah sebuah kata dalam bahasa Indonesia dari kata dasar "kerja" yang menerjemahkan kata dari bahasa asing prestasi. Bisa pula berarti hasil kerja.

Pengertian kinerja dalam organisasi merupakan jawaban dari berhasil atau tidaknya tujuan organisasi yang telah diterapkan.

\section{Faktor-faktor yang mempengaruhi kinerja:}

Faktor-faktor yang mempengaruhi pencapaian kinerja adalah faktor kemampuan (ability) dan faktor motivasi (motivation). Beberapa faktor yang mempengaruhi pencapaian kinerja atau prestasi kerja adalah faktor kemampuan (ability) dan faktor motivasi (motivation). Kinerja atau prestasi kerja seseorang merupakan gabungan dari tiga faktor penting yaitu:

1. Kemampuan, perangai, minat

2. Kejelasan, dan penerimaan atas penjelasan seorang pekerja

3. Tingkat motivasi.

Kinerja seseorang dapat diukur berdasarkan 6 kriteria yang dihasilkan dari pekerjaan yang bersangkutan. Keenam kriteria tersebut adalah :

\section{a. Kualitas}

Kualitas merupakan tingkatan dimana hasil akhir yang dicapai mendekati sempurna dalam arti memenuhi tujuan yang diharapkan oleh perusahaan.

b. Kuantitas

Kuantitas adalah jumlah yang dihasilkan yang dinyatakan dalam istilah sejumlah unit kerja ataupun merupakan jumlah siklus aktivitas yang dihasilkan.

c. Ketepatan waktu

Tingkat aktivitas di selesaikannya pekerjaan tersebut pada waktu awal yang diinginkan.

d. Efektifitas

Efektifitas merupakan tingkat pengetahuan sumber daya organisasi dimana dengan maksud menaikkan keuntungan.

e. Kemandirian

Karyawan dapat melakukan fungsi kerjanya tanpa meminta bantuan dari orang lain.

f. Komitmen

Komitmen berarti bahwa karyawan mempunyai tanggung jawab penuh terhadap pekerjaannya. 


\subsubsection{Kecerdasan Emosional dan Kinerja}

Seseorang yang dapat mengontrol emosinya dengan baik maka akan dapat menghasilkan kinerja yang baik pula. maka hasil yang didapat menunjukan bahwa karyawan yang memiliki skor kecerdasan emosi yang tinggi akan menghasilkan kinerja yang lebih baik yang dapat dilihat dari bagaimana kualitas dan kuantitas yang diberikan karyawan tersebut terhadap perusahaan. Chermiss juga mengungkapkan bahwa walaupun seseorang tersebut memiliki kinerja yang cukup baik tapi apabila dia memiliki sifat yang tertutup dan tidak berinteraksi dengan orang lain secara baik maka kinerjanya tidak akan dapat berkembang.

\subsubsection{Kecerdasan Spiritual dan Kinerja}

Kecerdasan spiritual mengajarkan orang untuk mengekspresikan dan memberi makna pada setiap tindakannya, sehingga bila ingin menampilkan kinerja yang baik maka dibutuhkan kecerdasan spiritual. Seseorang yang membawa makna spiritualitas dalam kerjanya akan merasakan hidup dan pekerjaannya lebih berarti. Hal ini mendorong dan memotivasi dirinya untuk lebih meningkatkan kinerja yang dimilikinya, sehingga dalam karir ia dapat berkembang lebih maju. Para pekerja mendapatkan nilai-nilai hidup bukan hanya dirumah saja, tetapi mereka juga mencari setiap makna hidup yang berasal dari lingkungan kerja mereka. Hal tersebut tergantung dari masing-masing pribadi orang tersebut dalam memberikan makna pada hidupnya.

Dari uraian yang telah dijelaskan maka dapat digambarkan sebuah kerangka pemikiran:

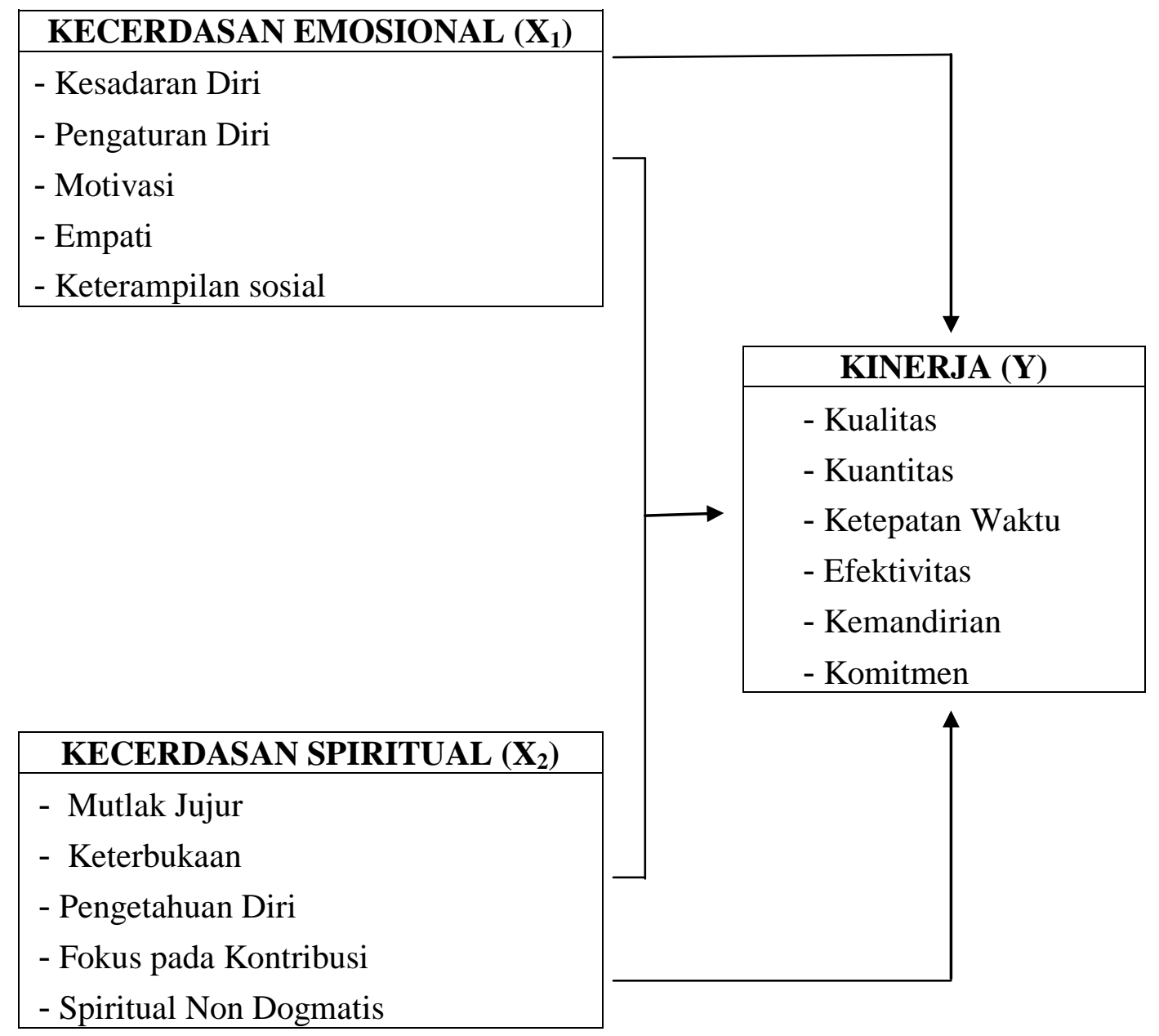




\section{METODE PENELITIAN}

\subsection{Objek Penelitian}

Obyek dalam penelitian ini adalah kantor Badan Pemeriksa Keuangan wilayah Lampung yang berlokasi di Jalan Pangeran Emir M. Noer No.24 Bandar Lampung.

\subsection{Populasi dan Sampel}

\subsubsection{Populasi}

Populasi adalah wilayah generalisasi yang terdiri atas obyek atau subyek yang mempunyai kualitas dan karakteristik tertentu yang ditetapkan oleh peneliti untuk dpelajari dan kemudian ditarik kesimpulannya (Sugiono, 2005 :72).

Adapun yang menjadi populasi dari penelitian ini Auditor Badan Pemeriksa Keuangan Wilayah Lampung yang berjumlah 55 orang.

\subsubsection{Sampel}

Sampel adalah bagian dari jumlah dan karakteristik yang dimiliki oleh populasi tersebut (Sugiono, 2005: 73). Menurut Istijanto (2006:109) yang dimaksud dengan sampel adalah merupakan bagian dari populasi. Dalam penelitian ini, penentuan sampel dilaku dengan menggunakan Rumus Slovin $\mathrm{n}=$

$$
\mathrm{n}=\frac{\mathrm{N}}{1+\mathrm{N}\left(\mathrm{a}^{2}\right)}
$$

Keterangan :

$$
\mathrm{N}=\text { Jumlah Populasi }
$$

$\mathrm{n} \quad=$ Jumlah Sampel

$\alpha \quad=$ Tingkat presisi yang diingin $=0,05(5 \%)$

\section{3 Pengumpulan Data}

\subsubsection{Sumber Data dan Jenis Data} yaitu :

Data dan informasi yang diperlukan dalam penelitian ini berdasarkan dari dua sumber

a. Data primer ini merupakan data yang diperoleh secara langsung dari objek penelitian dengan cara kuesioner.

b. Data skunder yang diperoleh berdasarkan dokumentasi yang ada pada kantor Badan Pemeriksa Keuangan Wilayah Lampung.

\subsubsection{Metode Pengumpulan Data}

a. Penelitian Lapangan (Field Research)

Penulis melakukan penelitian dengan langsung ke Kantor Badan Pemeriksa Keuangan Wilayah Lampung untuk memperoleh data-data yang berkaitan dengan penelitian yang dilakukan, dengan cara:

a. Observasi

Dalam hal ini penulis melakukan peninjauan ke lokasi dan mengadakan pengamatan pada kantor Badan Pemeriksa Keuangan Wilayah Lampung guna memperoleh data sebagai bahan penyusunan skripsi. 
b. Kuisioner

Yaitu pengumpulan data yang dilakukan dengan cara menyebarkan daftar pertanyaan yang sudah tersedia alternatif jawaban yang berhubungan dengan penelitian.

c. Dokumentasi

Yaitu pengumpulan data dengan cara mengunakan laporan maupun data statistik yang ada pada kantor Badan Pemeriksa Keuangan Wilayah Lampung.

\subsection{Operasional dan Pengukuran Variabel}

\subsubsection{Operasional Variabel}

Variabel-variabel yang merupakan fokus dari penelitian ini adalah:

\section{a. Variabel Bebas (Independent Variabel)}

Variabel bebas adalah variabel yang menjadi sebab timbulnya atau berubahnya variabel terikat, yang berarti variabel bebas adalah variabel yang mempengaruhi. Dalam penelitian ini, yang termasuk dalam variabel bebas adalah Kecerdasan Emosional $\left(\mathrm{X}_{1}\right)$ dan Kecerdasan Spiritual $\left(\mathrm{X}_{2}\right)$.

Definisi operasional variabel bebas adalah sebagai berikut:

1. Kecerdasan emosional adalah kemampuan untuk menggunakan emosi secara efektif dalam mengelola diri sendiri dan mempengaruhi hubungan dengan orang lain. Adapun indikator dari kecerdasan emosional adalah:

- Kesadaran Diri

- Pengaturan Diri

- Empati

- Motivasi

- Keterampilan Sosial

2. Kecerdasan spiritual adalah kecerdasan untuk menghadapi persoalan serta menempatkan perilaku dan hidup kita dalam konteks makna yang lebih luas dan kaya, kecerdasan untuk menilai bahwa tindakan atau jalan hidup seseorang lebih bernilai dan bermakna. Indikator dari kecerdasan spiritual adalah:

- Mutlak Jujur

- Keterbukaan

- Pengetahuan diri

- $\quad$ Fokus pada kontribusi

- $\quad$ Spiritual non dogmatis

\section{b. Variabel Terikat (Dependent Variabel)}

Variabel terikat adalah variabel yang dipengaruhi atau yang menjadi akibat adanya variabel bebas. Dalam penelitian ini, yang merupakan variabel terikat adalah Kinerja (Y). Kinerja adalah seperangkat hasil yang dicapai serta merujuk pada tingkat pencapaian serta pelaksanaan sesuatu pekerjaan yang diminta. Indikator dari kinerja adalah:

- Kualitas

- Kuantitas

- Ketepatan waktu

- Efektifitas

- Kemandirian

- Komitmen 
Sedangkan definisi dari auditor sendiri dalam penelitian ini adalah pejabat fungsional pegawai negeri sipil di lingkungan Instansi Pemerintah sesuai dengan peraturan perundangundangan atau auditor profesional yang bekerja di Instansi pemerintah yang tugas pokoknya melakukan audit (pemeriksaan) atas pertanggungjawaban keuangan yang disajikan oleh unitunit organisasi dalam pemerintah atau pertanggungjawaban keuangan yang ditujukan kepada pemerintah.

Indikator dari setiap variabel di atas dijadikan dasar untuk menyusun daftar pertanyaan yang diberikan kepada responden. Data yang terkumpul melalui daftar pertanyaan merupakan data kualitatif kemudian selanjutnya diubah menjadi data kuantitatif dengan cara pemberian nilai pada masing-masing jawaban, terdapat 5 skala tingkatan nilai yaitu :

\begin{tabular}{|ll|ll|}
\hline \multicolumn{3}{|c|}{ Variabel X } & \multicolumn{1}{c|}{ Variabel Y } \\
\hline SS & : Sangat Sering , skor 5 & SS & : Sangat Setuju, skor 5 \\
S & : Sering, skor 4 & S & : Setuju, skor 4 \\
KK & : Kadang-kadang, skor 3 & RR & : Ragu-ragu, skor 3 \\
SK & : Sekali-sekali, skor 2 & TS & : Tidak Setuju, skor 2 \\
TP & : Tidak Pernah, skor 1 & STS & : Sangat Tidak Setuju, skor 1 \\
\hline
\end{tabular}

\subsubsection{Pengukuran Variabel}

Untuk lebih jelasnya variabel dan indikator penelitian yang digunakan dapat dilihat pada tabel 1 dibawah ini.

Table 1. Variabel Penelitian dan Indikator Variabel

\begin{tabular}{|c|c|c|c|c|}
\hline NO. & VARIABEL & INDIKATOR & $\begin{array}{c}\text { ITEM } \\
\text { PERTANYAAN }\end{array}$ & SKALA \\
\hline \multirow[t]{5}{*}{1.} & \multirow{5}{*}{$\begin{array}{l}\text { Kecerdasan } \\
\text { Emosional }\end{array}$} & Kesadaran diri & $1-2$ & interval \\
\hline & & Pengaturan Diri & $3-4$ & interval \\
\hline & & Motivasi & $5-6$ & Interval \\
\hline & & Empati & $7-8$ & Interval \\
\hline & & $\begin{array}{l}\text { Keterampilan } \\
\text { Sosial }\end{array}$ & $9-10$ & Interval \\
\hline \multirow[t]{5}{*}{2.} & \multirow[t]{5}{*}{ Kecerdasan Spiritual } & Mutlak Jujur & $1-2$ & Interval \\
\hline & & Keterbukaan & $3-4$ & Interval \\
\hline & & Pengetahuan Diri & $5-6$ & Interval \\
\hline & & $\begin{array}{l}\text { Fokus Pada } \\
\text { Kontribusi }\end{array}$ & $7-8$ & Interval \\
\hline & & $\begin{array}{l}\text { Spiritual Non } \\
\text { Dogmatis }\end{array}$ & $9-10$ & Interval \\
\hline \multirow[t]{6}{*}{3.} & \multirow[t]{6}{*}{ Kinerja Auditor } & Kualitas Kerja & $1-3$ & Interval \\
\hline & & Kuantitas & 4 & Interval \\
\hline & & Ketepatan Waktu & $5-6$ & Interval \\
\hline & & Efektivitas & 7 & Interval \\
\hline & & Kemandirian & 8 & Interval \\
\hline & & Komitmen & $9-10$ & Interval \\
\hline
\end{tabular}




\subsection{Metode Analisis Data}

\subsubsection{Analisis Kualitatif}

Pada bagian ini akan dibahas mengenai hasil penelitian dengan memberikan penilaian terhadap jawaban responden melalui penyebaran kuisioner yang telah di isi responden. Skala yang digunakan adalah skala likert dan interval.

1. Interval mengetahui tanggapan responden terhadap variabel penelitian. Interval mempunyai kriteria penilaian $1-5$, dengan menggunakan rumus sebagai berikut :

Nilai Tertinggi - Nilai Terendah

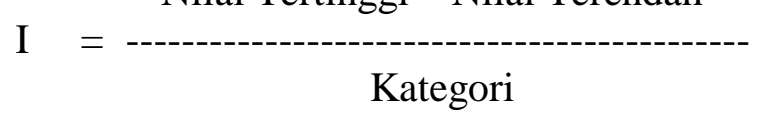

2. Skala likert untuk mengetahui tanggapan responden terhadap masing-masing butir instrumen indikator. Skala likert mempuyai kriteria penilaian 1 - 5, dengan demikian dapat dibuat kriteria penilaian sebagai berikut :

$\begin{array}{lll}20 \%-35 \% & = & \text { Sangat kurang baik } \\ 36 \%-51 \% & = & \text { Kurang baik } \\ 52 \%-67 \% & = & \text { Cukup baik } \\ 68 \%-83 \% & = & \text { Baik } \\ 84 \%-100 \% & = & \text { Sangat baik }\end{array}$

\subsubsection{Analisis Kuantitatif}

Secara kuantitatif penulis menganalisis dengan melakukan:

\section{a. Analisis Regresi Linier}

Dengan pendekatan Regresi Linier Berganda (Multiple Regression) melalui program komputer menggunakan sistem Statistical Packed For Social Science (SPSS) untuk mengetahui berapa besar pengaruh variabel-variabel independen $\left(\mathrm{X}_{1}\right.$ dan $\left.\mathrm{X}_{2}\right)$ terhadap variabel dependen $(\mathrm{Y})$, dimana dengan menggunakan persamaan rumus sebagai berikut:

$\mathbf{Y}=\mathbf{b}_{\mathbf{0}}+\mathbf{b}_{1} \mathbf{X}_{1}+\mathbf{b}_{2} \mathbf{X}_{2}+\mathbf{e}$

$$
\begin{array}{ll}
\text { Keterangan: } & \mathrm{b}_{0}=\text { konstanta } \\
& \mathrm{b}_{1}=\text { koefisien regresi dari variabel kecerdasan emosional } \\
& \mathrm{b}_{2}=\text { koefisien regresi dari variabel kecerdasan spiritual } \\
& \mathrm{X}_{1}=\text { kecerdasan emosional } \\
& \mathrm{X}_{2}=\text { kecerdasan spiritual } \\
\mathrm{e}=\text { error term }
\end{array}
$$

\section{b. Uji Hipotesis} berikut:

Pengujian terhadap hipotesis dalam penelitian ini dilakukan dengan cara sebagai

\section{- Uji Simultan (uji F)}

Uji $\mathrm{F}$ ini digunakan untuk mengetahui ada tidaknya pengaruh secara bersama sama (simultan) variabel-variabel independen (bebas) terhadap variabel dependen (terikat).

Pembuktian dilakukan dengan cara membandingkan nilai $\mathrm{F}_{\text {hitung }}$ dengan $\mathrm{F}_{\text {tabel }}$ pada tingkat kepercayaan $95 \%$.

Kriteria pengujian yang digunakan adalah : 
1. Bila $\mathrm{F}_{\text {hitung }}>\mathrm{F}_{\text {tabel}}$, maka $\mathrm{H}_{\mathrm{o}}$ ditolak, $\mathrm{H}_{\mathrm{a}}$ diterima.

Arti secara statistik data yang digunakan membuktikan bahwa semua variabel independen ( $\mathrm{X}_{1}$ dan $\mathrm{X}_{2}$ ) berpengaruh terhadap nilai variabel $(\mathrm{Y})$

2. Bila $\mathrm{F}_{\text {hitung }}<\mathrm{F}_{\text {tabel }}$, maka $\mathrm{H}_{\mathrm{o}}$ diterima, $\mathrm{H}_{\mathrm{a}}$ ditolak.

Arti secara statistik data yang digunakan membuktikan bahwa semua variabel independen $\left(\mathrm{X}_{1}\right.$ dan $\left.\mathrm{X}_{2}\right)$ tidak berpengaruh terhadap nilai variabel $(\mathrm{Y})$.

\section{- Uji Parsial (uji t)}

Uji t digunakan untuk mengetahui pengaruh masing-masing variabel bebas terhadap variabel terikat. Uji t dilakukan dengan membandingkan antara $\mathrm{t}$ hitung dengan $t_{\text {tabel. }}$. Untuk menentukan nilai $t_{\text {tabel }}$ ditentukan dengan tingkat kepercayaan $95 \%$.

Kriteria pengujian yang digunakan adalah :

Bila $\mathrm{t}_{\text {hitung }}>\mathrm{t}_{\text {tabel}}$, maka $\mathrm{H}_{\mathrm{o}}$ ditolak, $\mathrm{H}_{\mathrm{a}}$ diterima.

Bila $\mathrm{t}_{\text {hitung }}<\mathrm{t}_{\text {tabel}}$, maka $\mathrm{H}_{\mathrm{o}}$ diterima, $\mathrm{H}_{\mathrm{a}}$ ditolak.

\section{HASIL DAN PEMBAHASAN}

\subsection{Objek Penelitian}

Dalam penelitian ini yang menjadi objek penelitiannya adalah di kantor BPK Wilayah Lampung. Dalam melakukan penelitian, penulis mengambil 48 sample dari 55 Auditor dan pengambilan samplenya dilakukan secara acak.

\subsection{Deskripsi Karakteristik Responden}

1. Jenis Kelamin

Dari hasil penyebaran kuesioner terhadap 48 responden, diketahui bahwa 34 responden (71\%) adalah laki-laki dan sisanya sebanyak 14 orang (29\%) adalah perempuan.

2. Pendidikan

Dari hasil penyebaran kuisioner dengan 48 responden diketahui bahwa, pendidikan terakhir yang ditempuh responden sampai saat ini sudah cukup tinggi, karena 32 responden (67\%) berada pada jenjang Strata 1 dan 5 responden (11\%) berada pada jenjang Strata 2, dan 11 responden (22\%) jenjang Diploma.

3. Masa Kerja

Dari hasil perhitungan kuisioner terhadap lamanya bekerja responden pada kantor BPK diperoleh bahwa sebanyak 9 responden (19\%) bekerja antara 1-5 tahun, 21 responden (44\%) antara 6-10 tahun, 10 responden (21\%) antara 11-15 tahun dan sisanya 8 responden $(16 \%)$ telah bekerja lebih dari 16 tahun.

4. Usia

Berdasarkan informasi yang diperoleh dari 48 responden, diketahui bahwa 7 responden (15\%) berusia kurang dari 25 tahun, 14 responden (29\%) berusia antara 26-30 tahun, 21 responden (44\%) berusia antara 31-35 tahun, 4 responden (8\%) berusia antara 36-40 tahun dan 2 responden (4\%) berusia diatas 40 tahun. 


\subsection{Analisis Kuantitatif}

\subsubsection{Analisis Regresi Linier Berganda}

Berdasarkan hasil pengolahan data menggunakan program SPSS for Windows Version 18.0 sebagimana terlampir, maka diperoleh hasil untuk analisis regresi sebagai berikut:

Tabel 8. Tabel Coefficients ${ }^{\mathrm{a}}$

\begin{tabular}{|c|c|c|c|c|c|c|c|c|c|c|}
\hline \multirow{2}{*}{ Model } & \multicolumn{2}{|c|}{$\begin{array}{l}\text { Unstandardized } \\
\text { Coefficients }\end{array}$} & \multirow{2}{*}{$\begin{array}{c}\begin{array}{c}\text { Standardized } \\
\text { Coefficients }\end{array} \\
\text { Beta }\end{array}$} & \multirow{2}{*}{$\mathrm{t}$} & \multirow{2}{*}{ Sig. } & \multicolumn{3}{|c|}{ Correlations } & \multicolumn{2}{|c|}{$\begin{array}{l}\text { Collinearity } \\
\text { Statistics }\end{array}$} \\
\hline & B & $\begin{array}{l}\text { Std. } \\
\text { Error }\end{array}$ & & & & $\begin{array}{l}\text { Zero- } \\
\text { order }\end{array}$ & Partial & Part & Tolerance & VIF \\
\hline 1 (Constant) & 54,560 & 8,680 & & 6,286 & ,000 & & & & & \\
\hline $\begin{array}{l}\text { Kecerdasan } \\
\text { Emosional }\end{array}$ & ,323 & ,249 & ,945 & 4,287 & ,001 & ,624 &, 765 & ,765 & ,656 & 1,525 \\
\hline $\begin{array}{l}\text { Kecerdasan } \\
\text { Spiritual }\end{array}$ & ,653 & ,263 & ,546 & 2,479 & ,028 & ,008 & ,567 & ,442 & ,656 & 1,525 \\
\hline
\end{tabular}

a. Dependent Variable: Kinerja

Sedangkan Adjusted R Square pada tabel Model Summary ${ }^{\mathrm{b}}$ sebesar 0,522, yang dapat dilihat pada lampiran. Maka dari tabel diatas di dapat bentuk persamaan regresi berganda sebagai berikut:

\section{$Y=54,560+0,323 X_{1}+0,653 X_{2}$}

Berikut penjelasan berdasarkan regresi berganda yang terbentuk:

a. Koefisien regresi menunjukkan tanda positif $(+)$, hal ini berarti ada suatu kondisi yang searah yaitu peningkatan variabel $\mathrm{X}$ akan menyebabkan peningkatan variabel $\mathrm{Y}$.

b. Koefisien regresi kecerdasan emosional sebesar 0,323 berpengaruh menunjukkan bahwa kecerdasan emosional yang dimiliki seorang auditor akan berdampak pada peningkatan kinerja auditor atau jika kecerdasan emosional meningkat sebesar 1\% maka kinerja auditor akan meningkat sebesar 32,3\%.

c. Koefisien regresi kecerdasan spiritual sebesar 0,653 menunjukkan pengaruh terhadap kinerja auditor atau jika kecerdasan spiritual meningkat sebesar $1 \%$ maka kinerja auditor akan meningkat sebesar $65,3 \%$.

d. Koefisien determinasi (adjusted $\mathrm{R}^{2}$ ) sebesar 0,522 menginformasikan bahwa variasi kinerja auditor dapat dijelaskan oleh kedua variabel independen dalam penelitian ini yakni kecerdasan emosional dan kecerdasan spiritual sebesar 52,2 \% dan selebihnya, yaitu 47,8 \%, dijelaskan oleh faktor-faktor lain di luar penelitian penulis, seperti intelektual yang dimiliki auditor, kompetensi auditor, pengalaman auditor dalam pekerjaannya.

\section{KESIMPULAN DAN SARAN}

\subsection{Kesimpulan}

Setelah melakukan penelitian dan pengolahan data, maka penulis menarik kesimpulan bahwa kecerdasan emosional dan kecerdasan spiritual memiliki pengaruh terhadap kinerja auditor, hal ini didukung oleh: 
a). Berdasarkan hasil analisis kualitatif berdasarkan frekuensi jumlah responden tentang sebagian besar responden menyatakan kecerdasan emosional dan kecerdasan spiritual sudah baik, dan kinerja yang dimiliki auditor berada dalam katagori baik.

b). Berdasarkan hasil analisis terhadap score jawaban responden tentang kecerdasan emosional dan kecerdasan spiritual sudah baik artinya auditor memiliki kecerdasan emosional yang baik dan kecerdasan spiritual yang baik sehingga membuat kinerja yang dihasilkan oleh auditor baik.

c). Berdasarkan analisis regresi linier berganda, menunjukkan tanda positif (+). Hal ini berarti persamaan regresi linier berganda memiliki hubungan yang searah yaitu peningkatan variabel $\mathrm{X}$ akan menyebabkan peningkatan variabel $\mathrm{Y}$.

d). Berdasarkan pengujian hipotesis secara simultan ternyata $F_{\text {hitung }}(9,191)>F_{\text {tabel }}(3,81)$ maka Ho ditolak dan Ha diterima, yang berarti semua variabel independen $\left(\mathrm{X}_{1}\right.$ dan $\left.\mathrm{X}_{2}\right)$ berpengaruh terhadap variabel dependen (Y).

e). Berdasarkan pengujian hipotesis secara parsial pada kecerdasan emosional ternyata $t_{\text {hitung }}$ $(4,287)>t_{\text {tabel }}(1,753)$, maka Ho ditolak dan Ha diterima, yang berarti $X_{1}$ berpengaruh terhadap $\mathrm{Y}$,dan pada kecerdasan spiritual diperoleh $\mathrm{t}_{\text {hitung }}(2,479)>\mathrm{t}$ tabel $(1,753)$ yang berarti $\mathrm{X}_{2}$ berpengaruh terhadap $\mathrm{Y}$.

\subsection{Saran}

Untuk dapat lebih meningkatkan kinerja auditor maka perlu ditingkatkan kecerdasan emosional dan spiritual khususnya:

a. Perlunya ditingkatkan pengaturan diri auditor dengan beberapa cara diantaranya berhenti menuruti hal-hal yang menghasilkan perilaku-perilaku yang tidak produktif, tetap tenang, berfikir positif dan tidak bingung, bahkan pada saat keadaan sangat sulit, tetap terfokus meskipun berada dibawah tekanan sekalipun.

b. Perlu ditingkatkannya keterbukaan auditor dengan cara menyampaikan secara langsung hal yang dianggap tidak berkenan baik dari segi sikap maupun pekerjaan yang dilakukan oleh rekan kerja tanpa menyinggung perasaannya.

c. Tingkat kemandirian auditor juga perlu ditingkatkan agar supaya dalam mengerjakan tugas-tugasnya auditor tidak tergantung pada orang lain.

\section{DAFTAR PUSTAKA}

Agustian, Ary Ginanjar. Rahasia Sukses Membangun Kecerdasan Emosi dan Spiritual. Jakarta: ESQ. Arga, 2001.

Alwani, Ahmad. Pengaruh Kecerdasan Emosional Terhadap Kinerja Auditor pada Kantor Akuntan Publik di Kota Semarang. Skripsi Universitas Negeri Semarang, Semarang, 2007.

Cooper, R, K. Executive EQ : Kecerdasan Emosi Dalam Kepemimpinan dan Organisasi. Jakarta: PT. Gramedia Pustaka Utama, 2002.

Goleman, D. Emotional Intelligence : Mengapa EI lebih penting dari pada IQ. Jakarta: PT Gramedia Pustaka Utama, 1997.

Munir, Ningky. “Spiritualitas dan Kinerja,” Majalah Manajemen, Vol.124, Juli, 2000. 
Santoso, Purbayu Budi, M.S., Dr., dan Ashari, S.E., Akt. Analisis Statistik dengan Microsoft Excel dan SPSS. Yogyakarta: ANDI, 2005.

Setyawan, Dani. Analisis Pengaruh Kepemimpinan $Q(I Q, E Q, S Q)$ Terhadap Komitmen Organisasional Karyawan. Skripsi Universitas Katolik Soegijapranata, Semarang, 2004.

\section{Sumber website:}

$\underline{\text { www.google.com }}$

http:// alamsukawati.wordpress.com/ 2010/06/22/ kecerdasan-spiritual-dan pengaruhnyaterhadap-kinerja-karyawan/

http://id.wikipedia.org/wiki/Kinerja

http:// jurnalskripsi.com/ pengaruh-kecerdasan-emosional-dan-spiritual-auditor terhadapkinerja-auditor-dalam-kantor-akuntan-publik-pdf.htm 
Sengaja Dikosongkan 